\title{
O extraordinário do rio São Francisco em meio às incertezas do coronavírus
}

\author{
PÂMILLA VILLAS BOAS RIBEIRO \\ Universidade de São Paulo, São Paulo, São Paulo, Brasil \\ pamillaribeiro@usp.br
}

DOI 10.11606/issn.2316-9133.v29isuplp266-277

\begin{abstract}
resumo A partir do trabalho de campo realizado entre os ribeirinhos do município de Ponto Chique, no norte de Minas Gerais, busca-se refletir sobre como as incertezas constituem um modo de ser ribeirinho e nos ajuda a pensar sobre esse momento em que vivemos em estado de suspensão pelo coronavírus. As dinâmicas das águas impõem um modo de estar no mundo cercado de ambiguidades e a presença do vírus torna-se mais um elemento que integra a rede de sociabilidade ribeirinha. Opondo-se a uma ideia de controle da natureza, Olímpio e seus companheiros de vazante respeitam a natureza de cada ser e nos ensinam a interagir e nos relacionar com as diferentes espécies que habitam os territórios.
\end{abstract}

palavras-chave Vazanteiro. Ribeirinho. Multiespécie

The extraordinary of São Francisco River amid the uncertain of the coronavírus

abstract Based on the fieldwork carried out among the riverside residents of Ponto Chique, northern Minas Gerais, the article aims to reflect on how uncertainties constitute a way of being riverside and help us to think about this moment in that we live in a state of suspension by the Coronavirus. The dynamics of the waters impose a way of being in the world surrounded by ambiguities and uncertainties and the presence of the virus becomes another invisible element that integrates the riverside social network. Opposing an idea of nature control, Olimpio and his companions respect the nature of each being and teach us to interact and relate to the different species that inhabit the territories.

keywords Vazanteiro. Riverside. Multispecies

El extraordinario del río São Francisco y la incertidumbre del corona vírus

resumen Basado en el trabajo de campo realizado entre los ribereños del municipio de Ponto Chique, en el norte de Minas Gerais, el artículo reflexiona sobre cómo las incertidumbres constituyen una forma de ser de las poblaciones quienes viven cerca a 
los ríos y nos ayudan a pensar en este momento en el que vivimos en un estado de suspensión por el Coronavirus. La dinámica de las aguas impone una forma de estar en el mundo rodeada de ambigüedades y la presencia del virus se convierte en un elemento más que integra la red de sociabilidad fluvial. Oponiéndose a la idea de control de la naturaleza, Olimpio y sus compañeros respetan la naturaleza de cada ser y nos enseñan a interactuar y relacionarnos con las diferentes especies que habitan los territorios.

palabras clave "Vazanteiro". Poblaciones de los ríos. Mutiespecies.

\section{Introdução}

"A vida é um remanso: vai, volta, circula, ninguém sabe onde vai dar e nem pode saber". A frase do batuqueiro, ribeirinho e vazanteiro Olímpio Gonçalves pode iluminar esses tempos em que manejamos as incertezas. Essa frase aponta também para a forma com que os vazanteiros ${ }^{1}$ lidam com a dinâmica de uma vida construída na beira do rio. Nascido e criado nas margens do rio São Francisco, Olímpio já enfrentou enchentes, convive com as cheias e secas que ameaçam constantemente sua plantação. Esse território em que maneja sua existência está em constante remodelação tal qual o movimento do rio. Se a água do rio São Francisco corre de forma intensa, o marcador da paisagem para os ribeirinhos são justamente os remansos ${ }^{2}$, ou os pontos de circularidade. As dinâmicas das águas se tornam uma boa metáfora para pensar sobre a relação dos ribeirinhos com as múltiplas naturezas que circundam o rio São Francisco. Nesse processo de resiliência líquida ${ }^{3}$ os ribeirinhos convivem com as incertezas em uma vida multiespécie, ao contrário de nossas tentativas recorrentes de controle desse ambiente. Hoje, com a presença do coronavírus (Sars-Cov-2), encaramos o esfacelamento dessas certezas. Como aponta Tsing (2019) viver em indeterminação é uma forma de liberdade que compartilhamos com outras espécies. É justamente nessas trajetórias interativas que desenhamos o mundo enquanto vivemos nele. Assim se expressa o ecossistema ribeirinho.

\footnotetext{
${ }^{1}$ É o agricultor(a) que cultiva a terra nas margens do rio para a subsistência. As terras das margens do rio são de propriedade do Estado e existe uma tensão entre os ribeirinhos, governo e fazendeiros na disputa pelo território.

${ }^{2}$ De acordo com Olímpio, os remansos são os locais em que a água do Rio São Francisco faz um movimento circular. Esses locais estão próximos às encostas e são mais profundos. Quando o rio está cheio, pode ser perigoso remar em um remanso e não conseguir retirar a embarcação desse local, que fica estagnada. Os remansos são tão importantes para os ribeirinhos dessa região que recebem nomes específicos como remanso do fogo ou remanso do pai Tomás. Os remansos são também locais mais propícios de se encontrar os caboclos d'água apontando para essa dimensão em que a natureza não se separa dos seres humanos e não humanos que habitam o mesmo território.

${ }^{3}$ Utilizo essa expressão inspirada por Mário Mendiondo em sua apresentação "Rios em transe: eternos heróis de resiliência líquida” no encontro “SIMBIOSES - Água, matéria viva”, realizado em 2019 na Unicamp.
} 
O relato tem como ponto de partida uma das etapas do trabalho de campo para o doutorado em Antropologia Social na USP, realizada em Ponto Chique ${ }^{4}$, município localizado no norte de Minas Gerais, em março de 2020. Em campo, pude vivenciar o momento da chegada da pandemia no território durante 15 dias. Apesar da curta permanência nesta etapa, por causa das medidas de distanciamento social, foi possível perceber a maneira como os ribeirinhos manejaram a natureza do coronavírus em seu cotidiano.

Nessa vida em que o extraordinário se torna o cotidiano a presença do vírus tornase mais um elemento que integra a rede de sociabilidade ribeirinha. Não se trata, no entanto, de evitar qualquer tipo de cuidado ou de naturalizar as mortes e as perdas que o vírus pode causar. Trata-se, ao contrário, de respeitar a natureza do vírus. Vivendo na beira do rio, Olímpio respeita a natureza de cada ser, interage com suas dinâmicas, deixa o rio comer seu feijão para que ele também o coma, sabe que o vírus carece de atenção, mas percebe que ao respeitar a natureza do vírus, torna-se mais possível que sua vida na beira do rio não seja abalada. Expressar essas relações esteticamente, num teatro do cotidiano, torna tangível esse modo de vida ribeirinho.

Ao cunhar o conceito de teatro ambiental, Schechner (1968) pensa o evento teatral como um emaranhado de elementos. É justamente nesse intercâmbio que se encontra aquilo que se configura como a raiz do teatro: a troca de estímulos sensoriais ou ideológicos. "Uma relação viva entre os espaços do corpo e os espaços através dos quais o corpo se move. [...] Os exercícios com o espaço se constroem a partir do pressuposto de que tanto os seres humanos como o espaço estão vivos” (SCHECHNER, 1987, p.19).

Cada terra tem uma natureza, o rio tem uma natureza, assim como os humanos e animais, cada um, uma natureza própria e inter-relacionada. "Quando um bicho de estimação seu morre, é você que deveria ter morrido. Ele morreu para que você estivesse vivo hoje", me explicou Olímpio.

Essas naturezas estão interligadas num processo de assembleia (TSING, 2019) em que espécies variadas influenciam umas às outras. Nessa paisagem multiespécie, que envolve a vida na beira do rio São Francisco, pessoas sociais de muitas espécies interagem, moldando as vidas uns dos outros (TSING, 2019, p.64). Num íntimo relacionamento simbiótico $^{5}$, homens e animais formam uma única comunidade como exemplo de uma relação respeitosa dos humanos em relação aos não humanos. "Em vez de

\footnotetext{
${ }^{4}$ Ponto Chique é um município com 4.259 habitantes e que margeia o rio São Francisco. Conta com uma população formada por servidores públicos, pescadores e agricultores. Os vazanteiros que vivem e trabalham nas áreas inundáveis do Médio São Francisco, mais precisamente na região Norte de Minas Gerais, trazem consigo raízes indígenas e negras, com influência da vida ribeirinha da bacia. Essas comunidades são caracterizadas pelo modo de vida ligado ao rio, habitam as ilhas e barrancos do rio São Francisco e vivem para observá-lo, já que suas moradias e meios de sustento dependem do nível da água para realizar a pesca, agricultura, a criação animal e o extrativismo, associados aos ciclos da enchente, cheia, vazante e seca.

${ }^{5}$ A noção biológica de simbiose foi cunhada pelo botânico alemão Anton de Bary, em 1873, descrevendo a convivência, interação ou coabitação de organismos diferentes entre si.
} 
preservacionismo epitomizado nas unidades de conservação de florestas selvagens, há aqui um socioambientalismo que não prescinde da presença humana, mas a enovela no movimento de "linhas de dança" (TSING, 2019, p.29). Essa expressão é importante para refletirmos sobre a dimensão performática desse enovelamento na beira do rio em que narrativas, memórias, histórias, música e dança, praticados pelos ribeirinhos, não se separam do sistema bacia/palco em que habitam. Em outras palavras, nessa cenografia às margens do São Francisco, é o rio que se torna palco. A arte é justamente perceber esse entrelaçamento. "O mundo é feito na trajetória cruzada entre muitas espécies que vivem em comum e moldam as vidas uns dos outros (TSING, 2019, p.66)”.

Essa relação pode ser comparada a ideia de malha de Ingold: [o]rganismos e pessoas, então, não são tanto nós em uma rede quanto nós em um tecido de nós, cujos fios constitutivos, conforme se amarram a outros fios, em outros nós, compreendem uma malha”, (INGOLD, 2012, p.120).

\section{Natureza do vírus}

O ponto de vista dos ribeirinhos parece se distinguir do nosso comportamento padrão descrito pelo antropólogo Jean Segata que tem percebido nesse campo que envolve contaminações uma ideia de que a natureza é perigosa, que é externa à vida humana e social, e que os animais sendo seres da natureza oferecem algum risco e perigo.

Há uma certa exceção humana, a ideia de que estamos fora da caixa da natureza, que nos relacionamos com ela quando queremos, para nosso favor, nosso proveito, a gente trata ela como um recurso, tenta controlar a natureza - e nesse pacote entram os animais, os vírus, as bactérias etc. Mas, às vezes, as coisas escapam e a gente se dá conta que não está no controle de tudo nesse mundo (SEGATA, 2020b, s/p).

Os ribeirinhos pareciam compartilhar essa ideia de que a natureza não está sob nosso controle e servidão. Se hoje vivemos em desespero pelo coronavírus, sobretudo, pela sensação de que podemos perder tudo, os vazanteiros têm a experiência de perder tudo constantemente. Quando o lavrador planta muito feijão, ele perde para a enchente, quando planta pouco, percebe que deveria ter plantados mais. Olímpio plantou muito feijão para aproveitar a chuva de março, mas perdeu quase tudo, porque o rio encheu e comeu a plantação. Sem demonstrar nenhum tipo de revolta ou indignação, Olímpio apenas diz que prefere o rio comendo o feijão, do que perder para o sol e pela seca. Ele agradeceu a chuva e aguardava a potencial fartura no momento exato em que o rio para de encher, vaza um pouco, revigora e fertiliza a terra às margens do rio.

Tenho tentado mostrar que nós humanos não somos uma exceção, mas que estamos no mundo como os outros entes, numa relação política de 
que cada um possa ter seu espaço, só que a gente às vezes quer os espaços do outro e aí as coisas não dão certo, e a gente acaba se complicando, se contaminando. Isso aparece em outras dimensões, como há um mês, quando o Sudeste estava alagando e a gente dizendo 'a natureza é implacável, está levando vidas, é descontrolada etc.', como se a gente não tivesse implicação nenhuma na produção desses fenômenos que chamamos de naturais (SEGATA, 2020b, s/p).

A lição dos ribeirinhos com as constantes cheias, com a sua relação de respeito com os seres mágicos que povoam o rio, como o caboclo d'água ${ }^{6}$, é lembrar que nós não estamos em outra esfera, em outro universo (SEGATA, 2020). Os seus diálogos e encenações do cotidiano são uma maneira de evidenciar e expressar essa relação, por vezes conflituosa, por vezes respeitosa, com esses outros seres.

"Não existe dois medos nessa vida". Olímpio (2016) usou essa frase para explicar o que foi a enchente de 1979 que quase inundou Ponto Chique. As cobras entravam nos barcos, ninguém mexia nelas, elas não comiam os ratos, todo mundo tentava se salvar da enchente. Essa cena se passou na beira do rio São Francisco quando a cidade de Ponto Chique foi parcialmente inundada em 1979. Esse relato suscita a imagem de uma arca de Noé de Olímpio. Nessa arca, na verdade uma canoa de madeira, os bichos se amontoaram quietos, ninguém mexia um no outro. A cobra não comeu o rato, Olímpio não assustou e tentou retirar a cobra do barco. Ela permaneceu ali bem quietinha e todos fizeram juntos essa travessia.

Essa travessia exemplificava momentos em que espécies tão distintas se juntam num propósito único que transcende possíveis não afinidades ou mesmo uma lógica de cadeia alimentar ${ }^{7}$. Percebendo um ao outro num momento extraordinário em que o rio mostra sua imponência, essas espécies optam por agir conjuntamente como um "nós" que habitam o mesmo território. Como aponta Segata (2020) quando se trata de saúde todos os seres estão interrelacionados. Essa ideia de um corpo múltiplo (MOL, 2002) ${ }^{8}$, articulado num processo fluido de produção de realidades múltiplas, se expressa no relato de Olímpio, um momento em que humanos e não-humanos se engajaram numa empreitada para se salvar da maior enchente que Olímpio já atravessou na vida. Essa passagem expressava

\footnotetext{
${ }^{6}$ É comum ouvir casos sobre o caboclo d'água que pode proteger ou mesmo virar uma canoa. Para garantir uma boa relação com ele, os ribeirinhos ofertam fumo e cachaça.

${ }^{7}$ Cadeia alimentar consiste na permanente transferência de matéria e energia entre os seres vivos que constituem um determinado ecossistema. De forma simplificada, podemos classificar como cadeia alimentar a sequência de organismos que servem de alimento uns para os outros. No relato de Olímpio, a cobra não exerceu sua função na cadeia alimentar comendo os ratos, eles optaram por pactuar juntos essa travessia.

${ }^{8}$ A concepção de corpo múltiplo de Mol (2002) nos mostra como os corpos estão imbuídos de significados nas diferentes instâncias de sua produção. Com a atenção voltada às práticas e suas manipulações, a autora revela como o corpo, o paciente, os médicos e as tecnologias produzem nossas concepções de saúde e doença.
} 
ainda a necessidade de percebermos o corpo não como algo único, mas enredado num emaranhado de práticas.

É claro que a gente tenta se defender, proteger os nossos, mas animais também morrem pelos mesmos vírus que nós morremos, então não é um jogo de algoz e vítima, e sim uma situação em que todos estamos suscetíveis a viver bem coletivamente, quanto adoecer coletivamente. (SEGATA, 2020, s/p).

É nesse vazio existencial, de uma cidade quase imersa e naufragada que Olímpio nos ensinou também uma forma diferente de gestão do medo. "Não existem dois medos nessa vida”. O medo uniu todo mundo. Cobras, ratos e Olímpio lidaram juntos com esse momento de desamparo. Enquanto nós parecemos gerir o medo e o vazio a partir de uma narrativa que opõe um algoz, no caso do coronavírus, os morcegos, os animais. Em momentos de desespero, com um vírus de transmissão fácil e ágil, voltamos a buscar amparo em alguma autoridade máxima, que possa juntar os pedaços desse mundo estilhaçado.

Olímpio parecia optar por navegar nesses pedaços do mundo compreendendo a natureza de cada ser onde o fragmento e as ambivalências são constituintes desses seres. Essa passagem pode ser percebida também como um processo de realinhamento de alianças entre as espécies num pacto realizado a partir de cruzamentos simbióticos de quem sabe viver-entre e morrer-entre as profundezas desse rio. Nesses fragmentos, abre-se espaço para a criação e uma outra imaginação numa convivência entre animais e humanos. Natureza é uma possibilidade de existir que é irrefutável onde cada uma dessas trilhas é simplesmente um fio em um tecido de trilhas que juntas compreendem a textura do mundo da vida. "Qualquer que seja a imagem escolhida, o crucial é que comecemos pelo caráter fluido do processo vital, onde os limites são sustentados graças ao fluxo de materiais através deles" (INGOLD, 2012:41).

\section{Tô indo pra vazante, vou correr do vírus}

"De graça Deus fez o mundo para receber defunto e ninguém quer morrer". A frase de João de Lió, também vazanteiro e batuqueiro ${ }^{9}$, representa bem a chegada das medidas sanitárias para conter o avanço do coronavírus em Ponto Chique e as vivências de seus moradores. Esses moradores eram, em sua maioria, barranqueiros, ribeirinhos, pescadores e vazanteiros. Enquanto na pequena e pacata cidade de Ponto Chique o carro de som da prefeitura circulava avisando sobre o novo vírus e sobre a necessidade de ficarem em casa,

\footnotetext{
${ }^{9}$ João de Lió é membro do batuque de Ponto Chique. O batuque, nesta região chamado também de carneiro ou lambeiro, é uma dança típica que sempre culmina no bater de ombros entre dois dançantes e está associado à religião católica e às danças afro-brasileiras.
} 
os vazanteiros e pescadores ${ }^{10}$ se refugiavam no porto da cidade, local de pesca, do movimento dos barcos e, além disso, um palco que recebia diariamente diálogos, vivências, encenações, o que chamei de "teatro dos vazanteiros" 11 . Nesse palco do imponderável, chamou minha atenção algumas cenas protagonizadas pelo novo vírus.

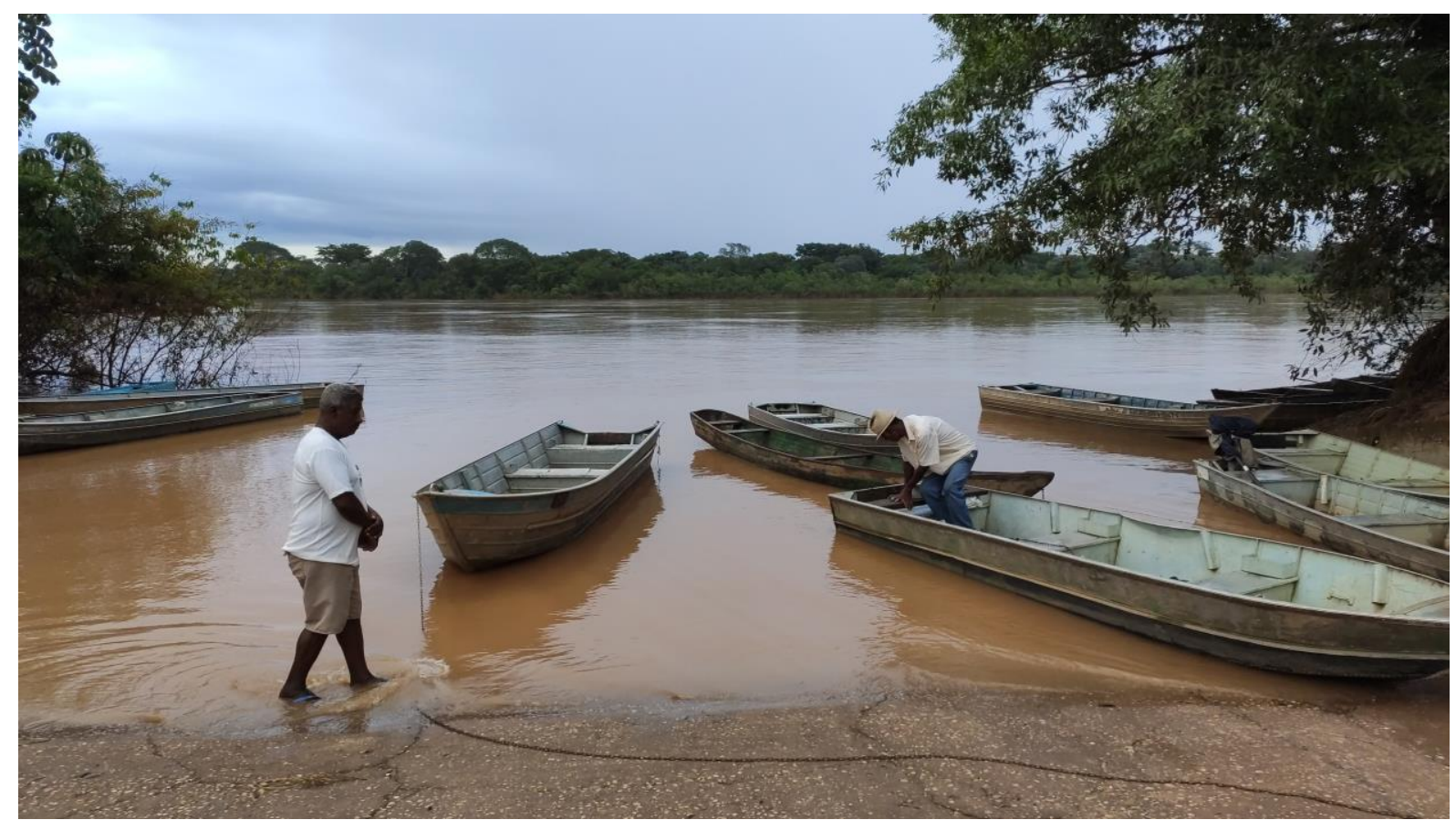

Figura 1. João do Lió e Olímpio. Fonte: Pâmilla Villas Boas Ribeiro, Março/2020.

Encontrei com Juquinha Sapateiro na beira do rio. Ele estava carregando sua canoa com mantimentos. "Tá indo ou tá chegando"? questionou um dos ribeirinhos. "Tô indo comer coronavírus", brinca Juquinha. Ele era hipertenso, tinha diabetes e decidiu passar os próximos meses em sua vazante. "Tô indo pra vazante, vou ficar lá uns 30 dias. Correr do vírus, sou hipertenso problema no coração”, nos explicou. A vazante de Juquinha fica longe da cidade no sentido do rio Paracatu, afluente do rio São Francisco.

Correr do vírus e comer o vírus. Fiquei pensando em como conseguiria os mantimentos necessários para permanecer esses meses na vazante, mas Juquinha estava preparado para pescar e havia levado alguns pacotes de arroz. Não vai precisar comer o vírus, como sugeriu, em forma de piada, os ribeirinhos que observavam a partida de Juquinha.

\footnotetext{
${ }^{10}$ Pude perceber que existe uma hierarquia entre vazanteiros e pescadores. A maioria dos vazanteiros têm embarcação própria, enquanto alguns pescadores utilizam as embarcações estacionadas no porto como local de pescar. Nem todo vazanteiro é pescador e vice e versa, categorias que precisam ser melhor analisadas.

${ }^{11}$ Da mesma forma como Dawsey (2005) reflete sobre a teatralidade dos bóias-frias em seu cotidiano no corte de cana, o cotidiano dos vazanteiros também é permeado pela teatralidade que expressam um modo de vida na beira do rio São Francisco.
} 


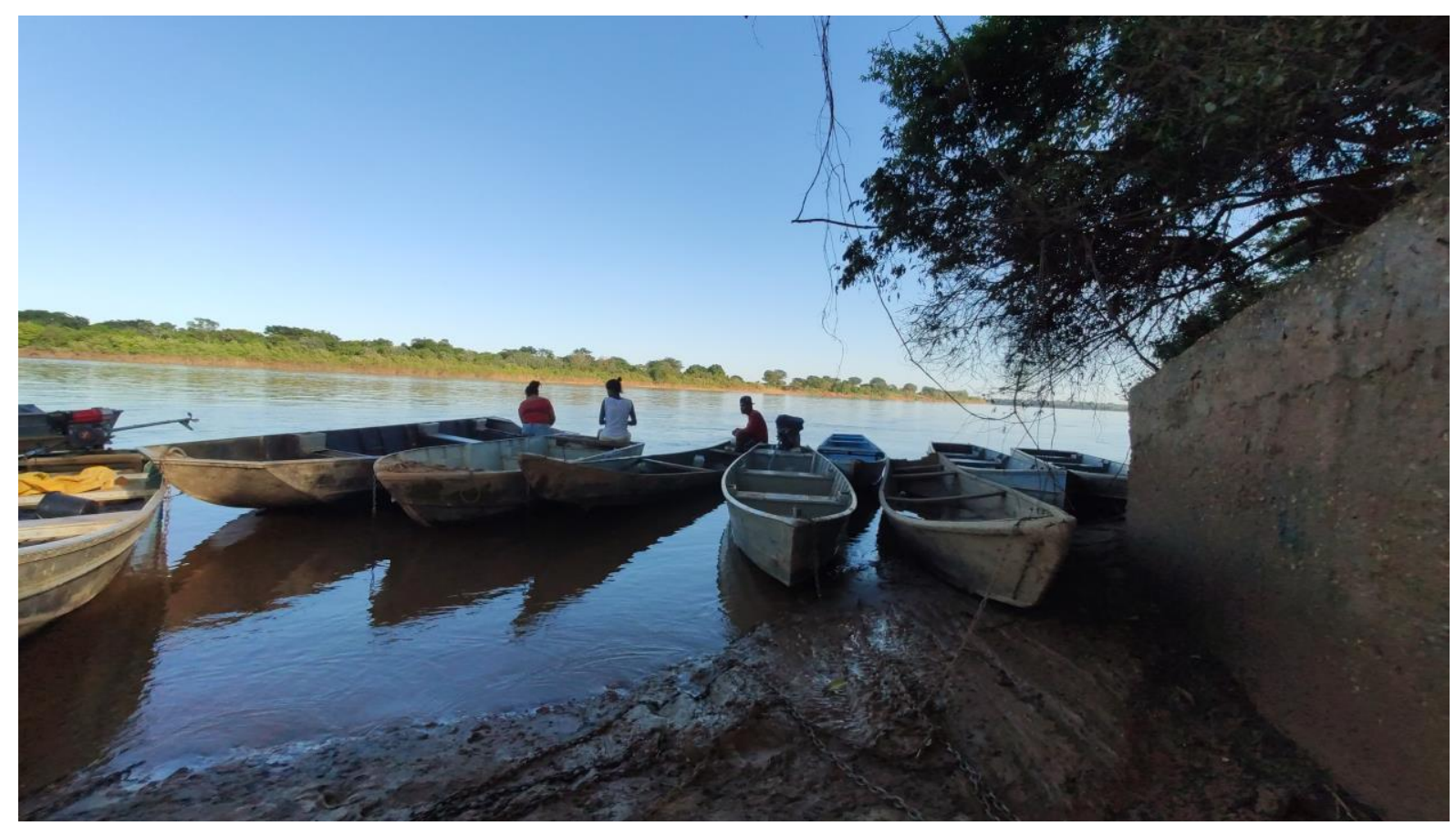

Figura 2. Pescadores na beira do rio. Fonte: Pâmilla Villas Boas Ribeiro, Março/2020.

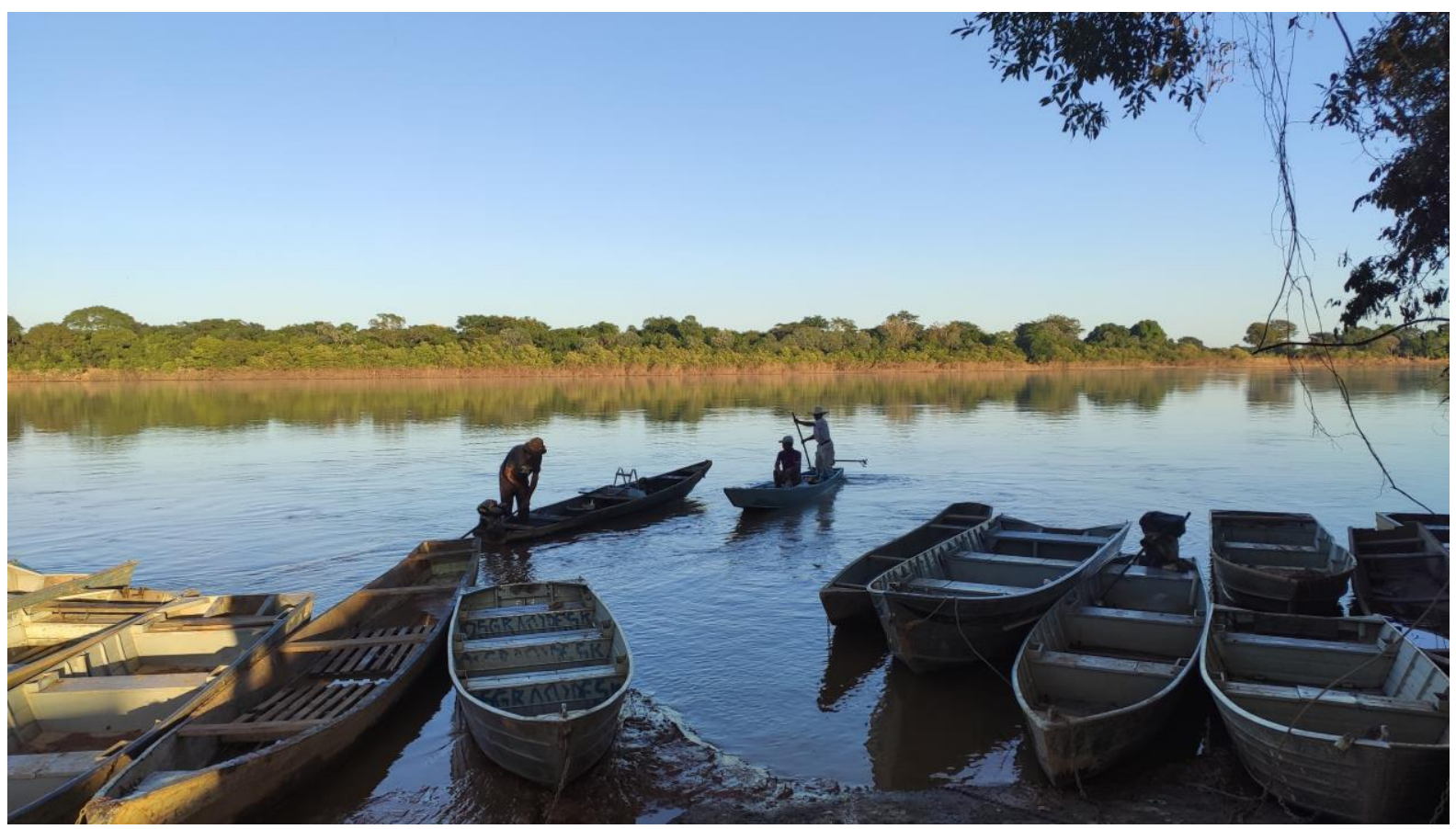

Figura 3. Movimento dos vazanteiros. Fonte: Pâmilla Villas Boas Ribeiro, Março/2020.

"Não pode só correr não, tem que atacar também", opina outro colega. Mas Juquinha sapateiro não duvida de sua escolha: "Dando tchau para essa cidade perigosa. Lá na vazante não tem visita”. Juquinha liga o motor do barco, despede-se de todos e segue viagem. 
Durante a minha estadia em campo, além do vírus, outro elemento modificava a vida dos ribeirinhos: a lama. Era época de enchente, época de fartura, mas também de perdas. Calcados nessa dualidade, a lama (conforme imagem 4) parece apontar para a difícil dinâmica de quem vive e produz na beira do rio, conforme este diálogo entre Olímpio e um jovem que pescava dentro de sua embarcação encostada no porto da cidade.

"Agora tá limpo", o menino diz. “Amanhã suja de novo” responde Olímpio.

A vazante é triste responde o menino. Todo dia é um dia diferente em estado de calamidade pelo Corona.

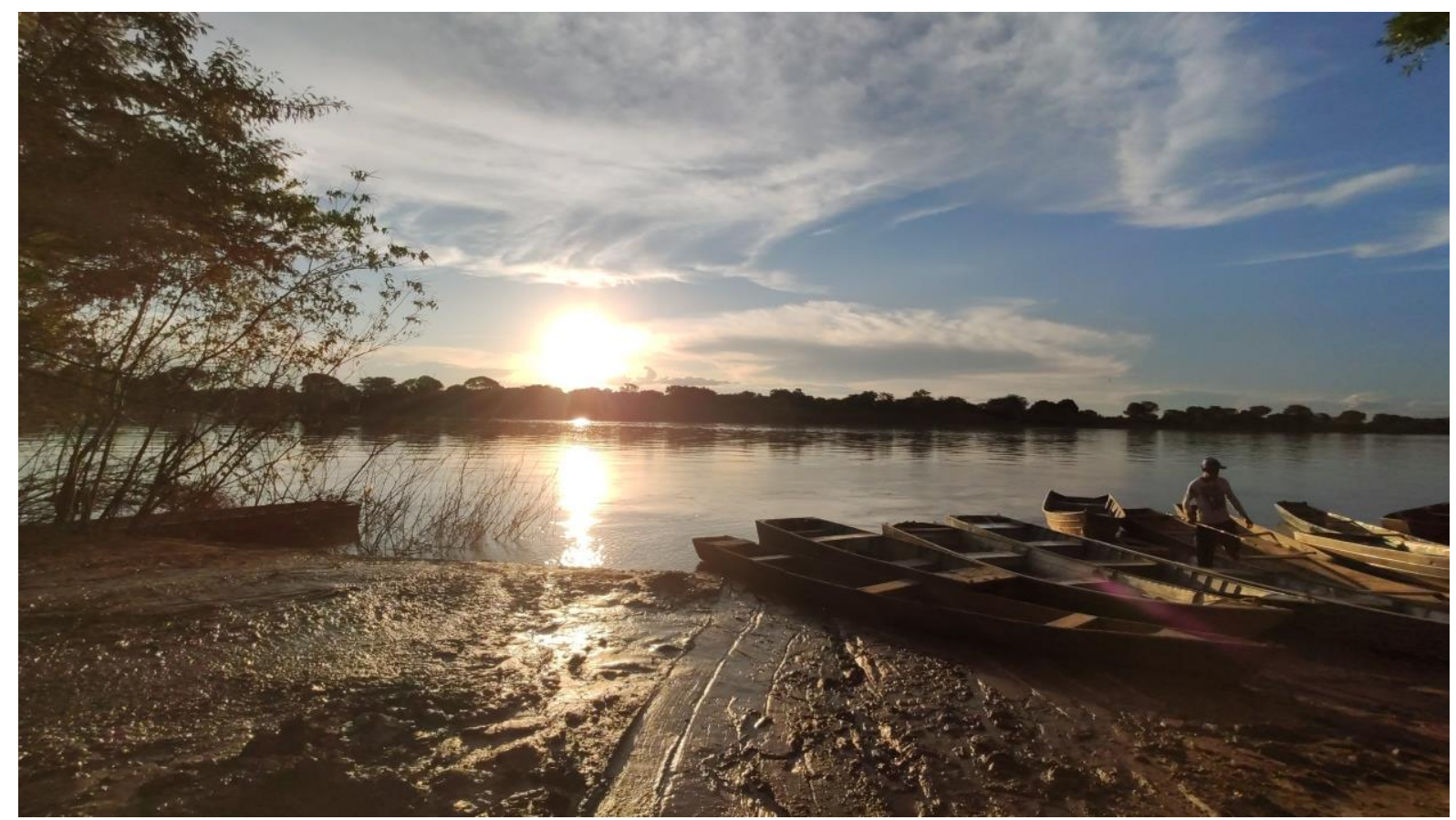

Figura 4. Lama no porto da cidade. Fonte: Pâmilla Villas Boas Ribeiro, Março/2020

Os vazanteiros lidam com a seca, com as enchentes e consequentemente com a lama que se forma no porto da cidade. A chuva pode comer a plantação, o sol pode comer a plantação, mas eles precisam comer o feijão e, em março, quem comeu mais feijão foi o rio São Francisco, me explicaram os vazanteiros. Além disso, com as constantes cheias - rio vai "render"- e nos consequentes momento de vazão da água - rio vai "vazar" - a lama era um elemento importante no cotidiano dos ribeirinhos de Ponto Chique. Era preciso, muitas vezes, "cair na lama”. Olímpio, por exemplo, hesitou em nos levar na sua vazante ${ }^{12}$ porque não sabia se teríamos condições de cair na lama. Mas conseguimos convencê-lo da

\footnotetext{
${ }^{12}$ Os territórios na beira do rio são de propriedade do Estado, mas os vazanteiros podem comprar um pedaço de terra para plantar e sua propriedade se reforça a partir dos usos e da interação com os demais vazanteiros. Nem todo ribeirinho tem uma vazante própria, já que é necessário recursos financeiros para "comprar" um pedaço de terra. Conceitos como território e propriedade são tensionados por esse direito de uso comercializável na beira do rio.
} 
empreitada. Cair na lama e correr do vírus marcavam a rotina da pacata cidade. Como nos explicava em uma conversa que tivemos em 2015: "todo lavrador é arrependido, quando planta muito chove pouco, quando planta pouco chove muito".

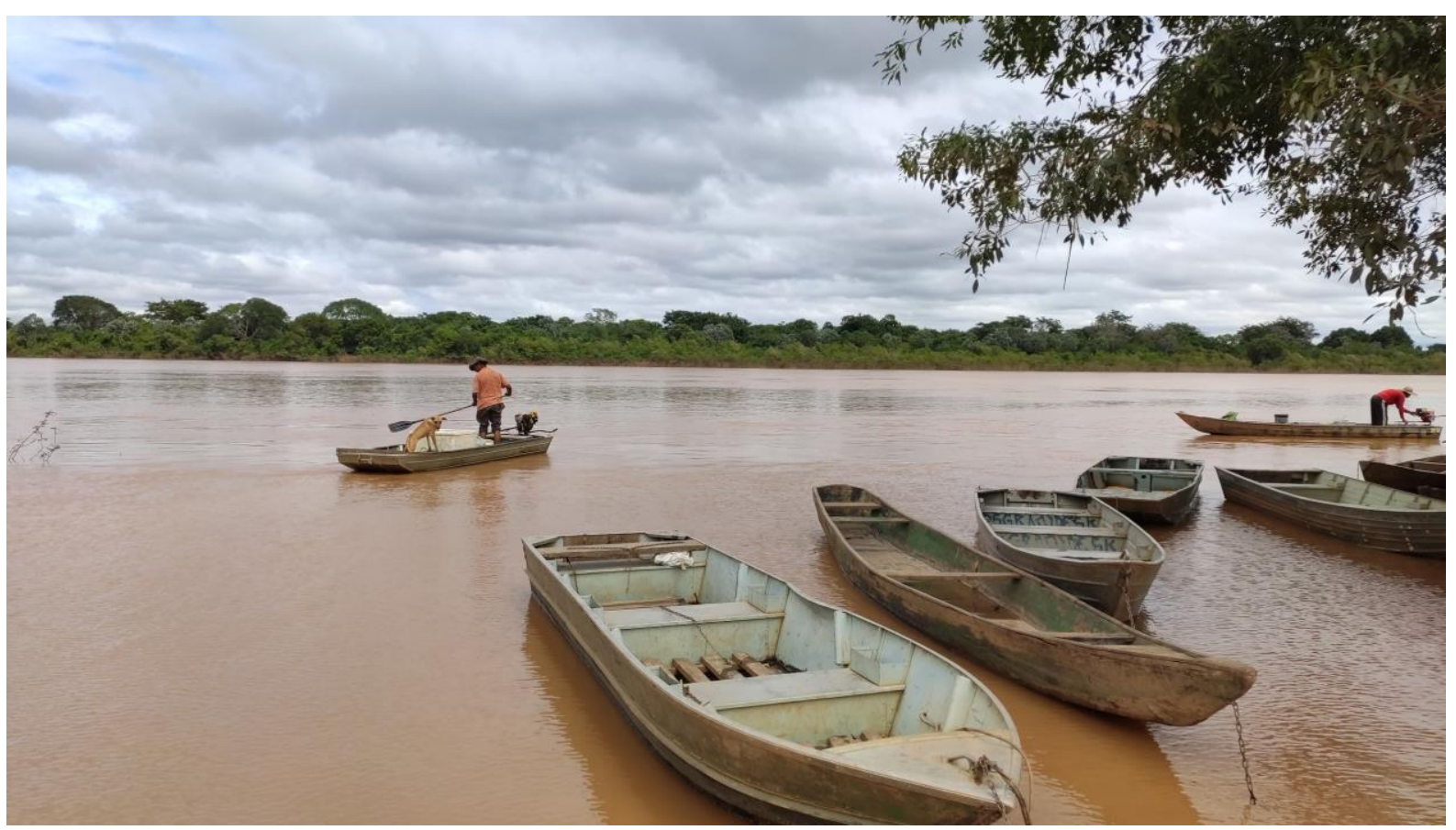

Figura 5. Cheia no rio. Fonte: Pâmilla Villas Boas Ribeiro, Março/2020

Como vimos nos diálogos acima é a partir de uma linguagem inventiva e aberta a múltiplas perspectivas que vazanteiros se comunicam em vários níveis de abstração. Esses fragmentos de oralidade rompem dicotomias e apontam para a dimensão relacional do pensamento ribeirinho com os sistemas ecológicos e de reprodução da vida. Podemos pensar que as funções poéticas desses diálogos, encenações e negociações compõe um imaginário ecológico a partir do improviso e da expressão dos aspectos criativos das ações sociais. Esse enraizamento e conexão, a partir da performance, enquanto ação, têm o poder de integrar e conectar pessoas no tempo e espaço (SPARTZ, 2019) configurando uma rede de relações nesse território.

"Eu num vou pegar o vírus. Diz que vírus é igual tatu", João de Lió comparava o vírus ao tatu ${ }^{13}$, animal que é cantado nas rodas de batuque. Encher barriga de fazendeiro, comer o vírus, cair na lama. Vazanteiro vai comer o vírus, rio come o feijão, fazendeiro come o produto do trabalho do ribeirinho e a carvoeira come seu próprio corpo. É comum as falas sobre a carvoeira como o pior lugar possível de se trabalhar. "Nós vale só enquanto tá movimentando e enchendo a barriga de fazendeiro e carvoaria”, me explicaram.

Enquanto o cotidiano de Olímpio era preenchido por uma dimensão estética no reconhecimento de cada detalhe que se modifica no rio, a relação com os seres e a morte

\footnotetext{
${ }^{13}$ Os tatus são cantados em diversas músicas dos batuques dessa região e aponta para a dimensão do sagrado que não pode ser revelado.
} 
pode ser explicada pelo próprio cotidiano do imponderável que permeia sua vida. $\mathrm{O}$ teatro dos vazanteiros, suas brincadeiras e encenações aponta também para nossa condição de Homo Ludens. Como aponta Dawsey (2005) ao analisar o teatro dos bóias-frias, uma etnografia desse cotidiano permite repensar a relação entre dramas sociais e dramas estéticos. Nesse cotidiano, a performance estética, característica de quem age num estado de distanciamento, torna-se cotidiana. "Performance social apresenta-se como performance estética também. A relação condensa-se. O estado liminar que se atribui ao ator durante a performance, descrito por Schechner, nos termos de Winnicott, como uma experiência de ser ao mesmo tempo "não-eu" e "não não-eu", torna-se cotidiano no caso dos “bóias-frias”" (DAWSEY, 2005, p.21).

Os atores multiespécies confrontavam e "invadiam" esses limites numa relação criativa e um regime de expressividade que tornava viva as naturezas em processo e movimento. "A aranha tecendo sua teia ou o músico lançando-se na melodia arrisca uma improvisação. Mas improvisar é juntar-se ao mundo ou fundir-se com ele. Aventurar-se de casa no fio de um sintoma (INGOLD, 2005, p.137)”.

Nesse estado de suspensão provocado por uma vida constantemente remodelada aparece o vírus que traz outra dimensão aos diálogos e encenações entre os vazanteiros. A morte surgia como tema de reflexão e suscitava muitas imagens de travessia, precipício, corpos construídos e destruídos. Nesse teatro, o rio virava palco e o coronavírus mais um ator em um mundo de incertezas. Uma malha que envolvia humanos e não humanos numa circularidade do remanso em que o imponderável marca o ritmo das múltiplas naturezas da vida.

\section{Referências bibliográficas}

DAWSEY, John C. (2005). "O teatro dos "bóias-frias": repensando a antropologia da performance.” Horizontes Antropológicos. vol.11, n.24. Porto Alegre, pp.15-34.

INGOLD, Tim. (2012) "Trazendo as coisas de volta à vida: emaranhados criativos num mundo de materiais”. Horizontes antropológicos, n.37, v.18. Porto Alegre, p. 25-44.

INGOLD, Tim. (2015). Estar vivo: ensaios sobre movimento, conhecimento e descrição. Petrópolis: Vozes.

MOL, Annemarie. (2002). The body multiple: ontology in medical practice. Londres: Duke University Press.

SCHECHNER, Richard. (2011). "Pontos de contato entre o pensamento antropológico e teatral”. Cadernos de campo, vol. 20, n.20. São Paulo, p.213-236.

SCHECHNER, Richard. (1987). “El Espacio”. In: El Teatro Ambientalista. Traducción: Alejandro Bracho. Cidade do México: Árbol Editorial.

SCHECHNER, Richard. (1968). Six Axioms for Environmental Theatre. The Drama Review: TDR, Vol. 12, No. 3, Architecture/Environment. pp.41-64.

SCHECHNER, Richard. (1994). Environmental theater. New York/London: Applause. 
SEGATA, Jean: "A epidemia é muito maior do que a doença, que o número de casos" Entrevista concedida ao jornalista Christian Bueller. Jornal Correio do Povo, Rio Grande do Sul, 17 de mai. de 2020.

SPARTZ, James. (2019). "Songwriting as Expression of Cultural Ecosystem Services". Trabalho apresentado durante a conferência Waterlines: Confluence and Hope through Environmental Communication. Vancouver (Canada), 17 de junho de 2019.

TSING, Anna. (2019). Viver nas ruínas: paisagens multiespécies no Antropoceno. Brasília: IEB/Mil Folhas.

sobre a autora

\section{Pâmilla Villas Boas Ribeiro}

É doutoranda no Programa de Pós-Graduação em Antropologia Social da Universidade de São Paulo. Também é mestra em Antropologia e bacharela em Comunicação social, ambos pela Universidade Federal de Minas Gerais. 